\title{
The assessment of potential physical impact of climate change on coastal reef habitats: A case study of the Latvian coast of the Baltic Proper
}

\author{
Aigars Lavrinovičs ${ }^{1 *}$, Maija Viška ${ }^{1,2}$, Sandra Sprukta ${ }^{1}$, Juris Aigars ${ }^{1}$ \\ ${ }^{1}$ Latvian Institute of Aquatic Ecology, Voleru iela 4, LV-1007, Riga, Latvia \\ ${ }^{2}$ Laboratory of Wave Engineering, Institute of Cybernetics at Tallinn University of Technology, Akadeemia 21, 12618 Tallinn, Estonia \\ ${ }^{\star}$ Corresponding author, E-mail: aigars.lavrinovics@lhei.lv
}

\begin{abstract}
The relation between climate change and biodiversity in coastal reefs was assessed in the region of the Latvian coast of the Baltic Proper. To quantify this relation, the characteristic wave heights, closure depth and sediment transport intensity were estimated using the third generation spectral wave model WAM and the world-wide acknowledged Coastal Engineering Research Council approach for sediment transport. The cumulative influence of physical properties in the coastal zone results was estimated by the physical impact index, which indicates the areas with the highest potential treat to coastal reef habitats. This index tends to increase from the south to north with the highest physical impact in the area between Akmensrags and south of Oviši village.
\end{abstract}

Key words: Baltic Proper, climate change, coastal reefs, habitats, physical impact.

Abbreviations: CERC, Coastal Engineering Research Council.

\section{Introduction}

Many studies have shown a global trend of increasing temperature as well as changes in salinity and ice regime in the seas and oceans during the last 100 years (Brohan et al. 2006; Eriksson et al. 2007; HELCOM 2013). These changes lead to significant alteration of waves and coastal currents in the Baltic Sea, which result in increasing coastal erosion and the transport of suspended matter along the coast. Due to its predominantly sandy shores, the sea coast in the south-eastern area of the Baltic Sea from the Sambian Peninsula to Cape Kolka is particularly sensitive to increased wave activity. As a result, it is transformed more intensively than the other bedrock-based coastal area of the Baltic Sea (Soomere et al. 2011; Eberhards, Lapinskis 2008).

Coastal erosion shows only the visible effects of climate change. During storm events coastal reefs are under the combined impact of wave activity and sediment transport which have abrasive effect, cause burial of sediments and, due to increased water turbidity, decrease light availability. This causes deterioration of functions and biological diversity of coastal reef habitats. The relationships between physical and biological factors are complicated due to effect of several physical pressures simultaneously.

The reefs along the Latvian coast of the Baltic proper are geological formations that were formed during the last ice age by glacial activity and melting. The reefs consist of a rocky seabed surrounded by sandy areas and are usually found at depths between 2 and $20 \mathrm{~m}$. The coastal reefs can be compared to an oasis, which is a habitat for various species of fish, macrophytes, invertebrates and seabirds. Reefs also provide a food source for seabirds, which makes these habitats an important component of the food web (Andrulewicz et al. 2004; Baltic Environmental Forum Latvia 2015). To some extent the functions provided by coastal reefs play a significant role in the economy of coastal areas, specifically in the fishing and fish processing industry. Healthy and well-functioning coastal reef habitat provides stable populations of commercial fish species that uses the reefs as spawning and nursing areas.

The current knowledge of climatic pressure on coastal habitats is rather theoretical and few such studies have been conducted. Understanding the relation between physical impact of wave activity and biodiversity of coastal habitats would increase the knowledge on climate change and its effect on natural resources. In addition, resource managers would be able to develop more effective and economically sound conservation strategies for coastal habitats, allowing to adapt to climate change and ensure environmental quality and sustainability of coastal waters.

The aim of this study was to develop an approach to assess cumulative impact of key physical pressures of the coastal zone. 


\section{Materials and methods}

\section{Study site}

The physical impact of wave activity on coastal habitats was assessed along the west coast of Latvia between the LatvianLithuanian border in the south and Oviši village in the north (Fig. 1). The shoreline of the study site was formed during the Quaternary period. It was shaped by the Scandinavian ice sheet and hydro-meteorological drivers after retreat of the ice sheet (Ulsts 1998). The coast coast is sedimentary and is formed on unconsolidated Quaternary sediments. The coast including underwater slope is relatively low and flat. Sandy beach is common along the coast (Lapinskis 2010). The seabed of the coastal zone mainly consists of sand, pebble and gravel (Pranzini, Williams 2013).

The distribution of the benthic biological community depends on the seabed type. The macrozoobenthic community in soft seabed areas consists of various crustacean, aquatic worm as well as mollusc species, which make up the largest zoobenthos biomass, with Macoma balthica being the dominant species (unpublished data from marine monitoring). In nearshore territories with rocky seabed the dominant species are Mytilus trossulus and Balanus improvisus.

Phytobenthos species are found only in coastal areas

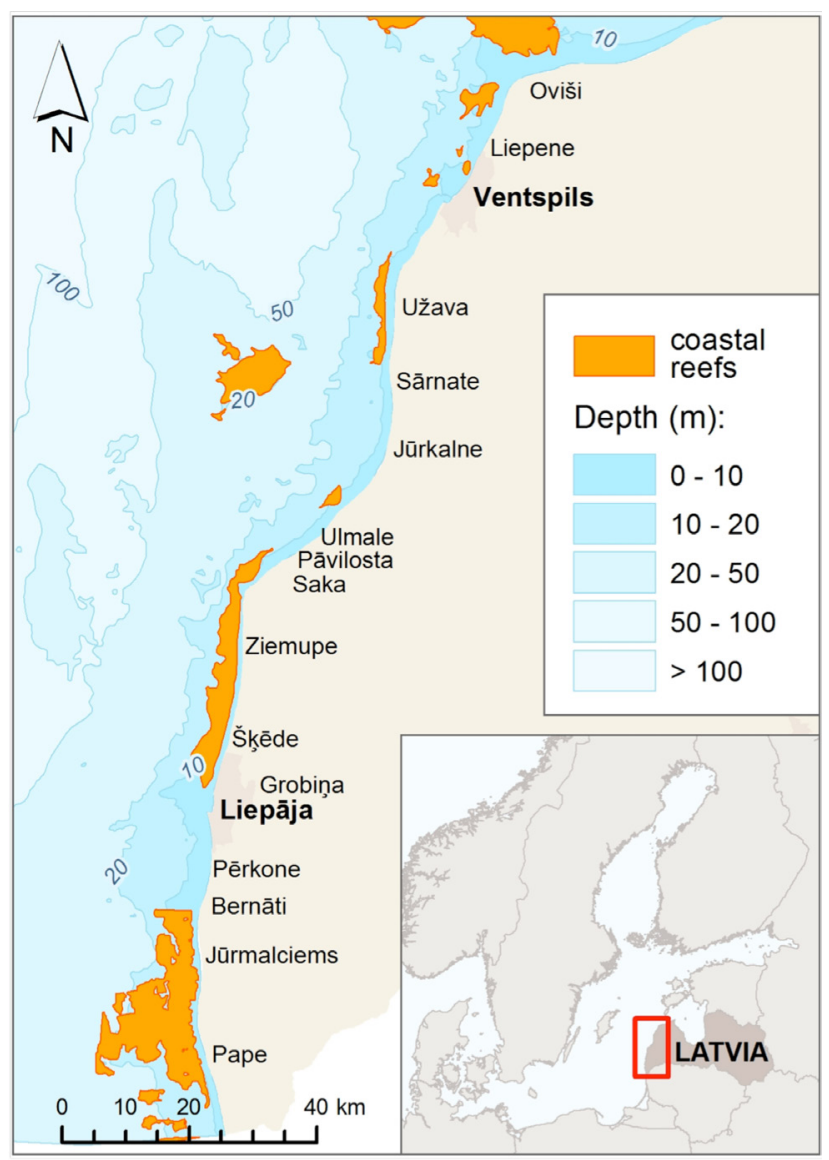

Fig. 1. Location of the study area on the Baltic Sea coast. with rocky seabed. In more shallow zones the reefs are covered mainly by Cladophora glomerata and Cladophora rupestris, but with an increasing depth Furcellaria lumbricalis is the dominant species.

The number of coastal fish species in the study site varies from 10 to 16 , increasing with the depth. The most common species in this area are Platichthys flesus and Perca fluviatilis.

There are several territories in the study area that are included in the Natura 2000 site network (Nature Conservation Agency 2010): Nida - Pērkone, Akmensrags and Irbe strait (partly) marine protected areas as well as nature parks in Pape and Bernāti and Ziemupe, Užava and Ovī̌si nature reserves, which are located in the mainland coast area of the study site.

\section{Evaluation of wave properties}

Among wave properties, wave height has the strongest direct effect on benthic habitats and also determines the depth of wave energy effect. To analyze the physical impact on biological diversity of coastal habitats, a mean wave height in a 12 hour period and maximum wave height during storm was used. These wave properties were estimated using the third-generation spectral wave model WAM (Komen et al. 1994). The model was run in the finite-depth mode for the entire Baltic Sea to the east of the Danish straits on a regular rectangular grid with a spatial resolution of 3' along latitudes and 6' along longitudes (Räämet, Soomere 2010). The wave model was forced with near-surface wind at a $10-\mathrm{m}$ level obtained from the Swedish Meteorological and Hydrological Institute geostrophic wind database and calibrated against satellite data (Kudryavtseva, Soomere 2016). In the model, Latvian coast from the border of Latvia and Lithuania to Oviši village was divided into 5.5 to $7 \mathrm{~km}$ long sections. These sections match the location of the geometric center of near-shore grid cells of the wave model.

Closure depth was defined as the maximum depth at which breaking waves effectively modify the nearshore profile (Hallermeier 1978; 1981). Seawards of the closure depth, storm waves may occasionally move bottom sediments, but are not able to maintain a specific profile. Closure depths were estimated from the second-order approximation that describes closure depth as a quadratic function of wave height and also includes the peak wave period (Birkemeier 1985; Houston 1996):

$$
h_{c}=p_{1} H_{0.137 \%}-p_{2} \frac{H_{0.137 \%}^{2}}{g T_{s}^{2}},
$$

where $g$ is the gravity alteration, $p_{1}=1.75$ and $p_{2}=57.9$ are constants and $T$ is the typical peak period that corresponds to $H_{0.137 \%}$, which is the largest significant wave height that occurs for $12 \mathrm{~h}$ annually. This approach gives acceptable estimates of closure depth for the open Baltic Sea coast of Latvia (Soomere et al. 2013). Each calculated value of quantiles of wave heights and closure depths reflect the 
numerically simulated wave climate over the time interval of 1970 to 2007.

\section{Evaluation of alongshore sediment transport}

The properties of wave-driven potential transport were evaluated using the most commonly, employed Coastal Engineering Research Council (CERC) method (USACE, 2002). This method is based on the assumption that wavedriven alongshore sediment transport is proportional to the wave energy flux per unit of length of the coastline. The description of the calculation scheme and used data are presented in detail (Viška, Soomere 2013).

\section{Results and discussion}

\section{Wave height}

The WAM model results show that the west coast of Latvia can be divided in four sections with respect to the potential wave height quantiles. The mean annual wave height for the mean height in a 12 -h period on average in a year (Fig. 2) showed a smooth and gradual increase in the direction from south to north. The coastal zone with the lowest potential wave height lay in the region between the LatvianLithuanian border and Ziemupe village, where wave height

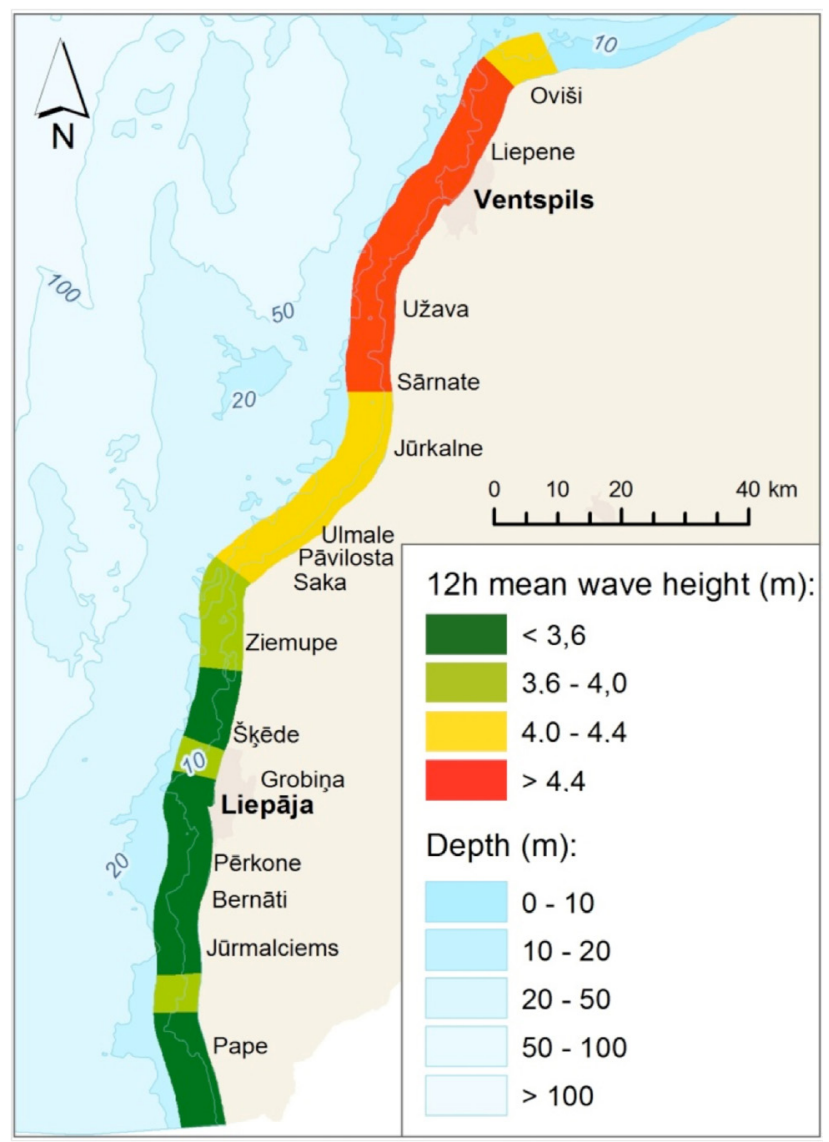

Fig. 2. 12-h mean wave height in the study area. The designated division of the parameter is not based on an actual scale and has only informative meaning. was between 3.4 and $3.6 \mathrm{~m}$. In a few short sections between these villages and around cape Akmeñrags, the potential 12-h mean wave height can reach $4 \mathrm{~m}$. The highest $12-\mathrm{h}$ mean wave height was for the region between Sārnate and Oviši villages, where it exceeds $4.4 \mathrm{~m}$ and reaches $4.7 \mathrm{~m}$. In other parts of the study site the wave height varied between 4 and $4.4 \mathrm{~m}$.

Although there are available wave height observations from hydro-meteorological stations in Liepāja, Pāvilosta and Ventspils, they cannot be compared to the estimated wave height, as they reflect wave height on the coast. The model results characterize wave height at least $3 \mathrm{~km}$ from the coast. However, satellite data that were used for model calibration show strong correlation with in situ measurements (Kudryavtseva, Soomere 2016).

The alongshore distribution of the maximum wave height during storm events was similar to the 12-h mean wave height (Fig. 3). The range of the maximum wave height was 6.8 to $10 \mathrm{~m}$. The lowest maximum wave height was common for the area between Pape and Škēede villages and around cape Akmeñrags. In two short coastal sections between the Latvian-Lithuanian border and Pape village and between Škēede and Ziemupe villages the maximum wave height reached 7.5 to $8.5 \mathrm{~m}$. Further north, between

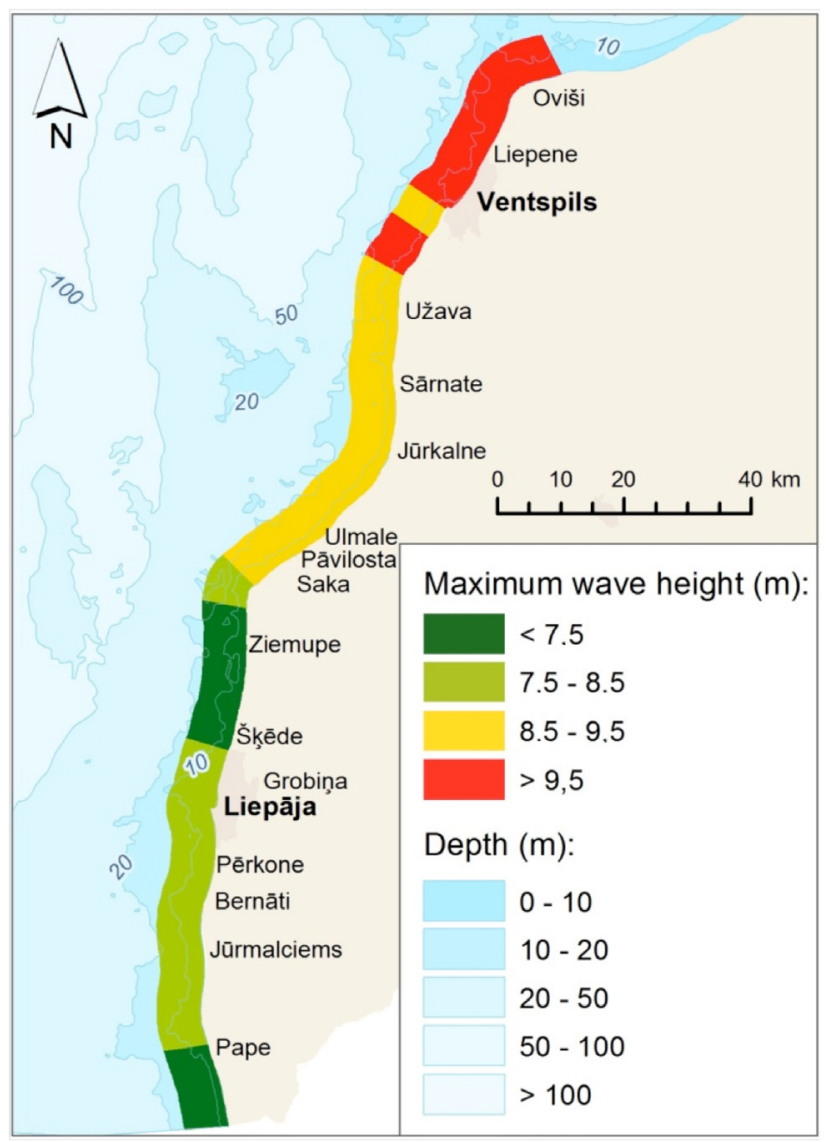

Fig. 3. Gradual division of the maximum wave height in the study area. The designated division of the parameter is not based on an actual scale and has only informative meaning. 
cape Akmeñrags and Užava village the maximum wave height was higher by one meter. The zone with the highest maximum wave height $(>9.5 \mathrm{~m})$ lay between Užava and Oviši villages with a short section in the area south of Ventspils.

The estimated wave height and its quantiles were further used as input data to quantify closure depth, sediment transport intensity and the physical impact index. Therefore, the alongshore distribution of these parameters largely corresponds to the wave height quantile used for their calculation.

\section{Closure depth}

In accordance with the estimated average and maximum closure depth values (Fig. 4 and 5) the coastal zone of the study site can be divided in three sections with different potential wave impact on coastal reef habitats, and the characteristic values within these sections did not vary substantially. The average estimated closure depth increased from south to north. For the coastal zone between the Latvian-Lithuanian border and Sārnate village, the average, estimated closure depth gradient varied from low to average with less than 5.2 to 5.4 and 5.4 to $6.3 \mathrm{~m}$ respectively. The estimated average closure depth in the coastal area between

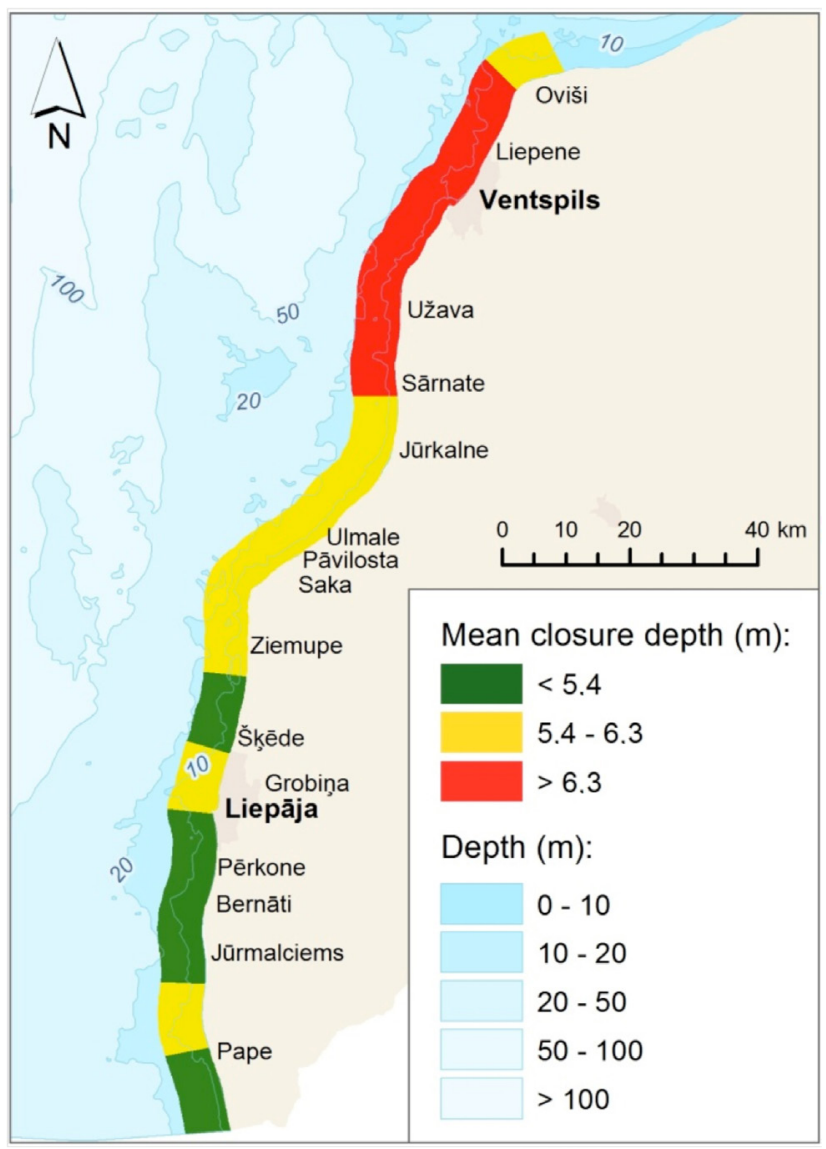

Fig. 4. Gradual division of the mean closure depth in the area. The designated division of the parameter is not based on an actual scale and has only informative meaning.
Sārnate and Ovišsi villages varied from 6.3 to $6.8 \mathrm{~m}$.

Maximum estimated closure depth (Fig. 5) was higher ino the northern sections and lower in the area south of Pāvilosta. Short coastal sections around Pāvilosta, north of Užava, and between Jūrmalciems and Šḳēde villages, had average maximum closure depth between 10.5 and $11.5 \mathrm{~m}$.

Although the closure depth along the Latvian coast of the Baltic Proper does not vary substantially, the areas with highest closure depth values can be attributed to the prevalence of frequent and stronger north-northwesterly winds (Soomere, Keevallik 2001), which generate among the highest wave intensities in the entire Baltic Proper. Areas with higher closure depth identifies areas with potentially larger sediment resuspension and transport rates. These processes place coastal reef habitats under more intensive physical impact, which can possibly result in abrasion and vegetation removal from the rock surface, as well as habitat burial by transported sedimentary material.

\section{Sediment transport intensity}

The sediment transport intensity characterizes the potential amount of sedimentary material that is moved along the coast by wave energy, which is an additional negative physical effect on coastal habitats. The distribution of

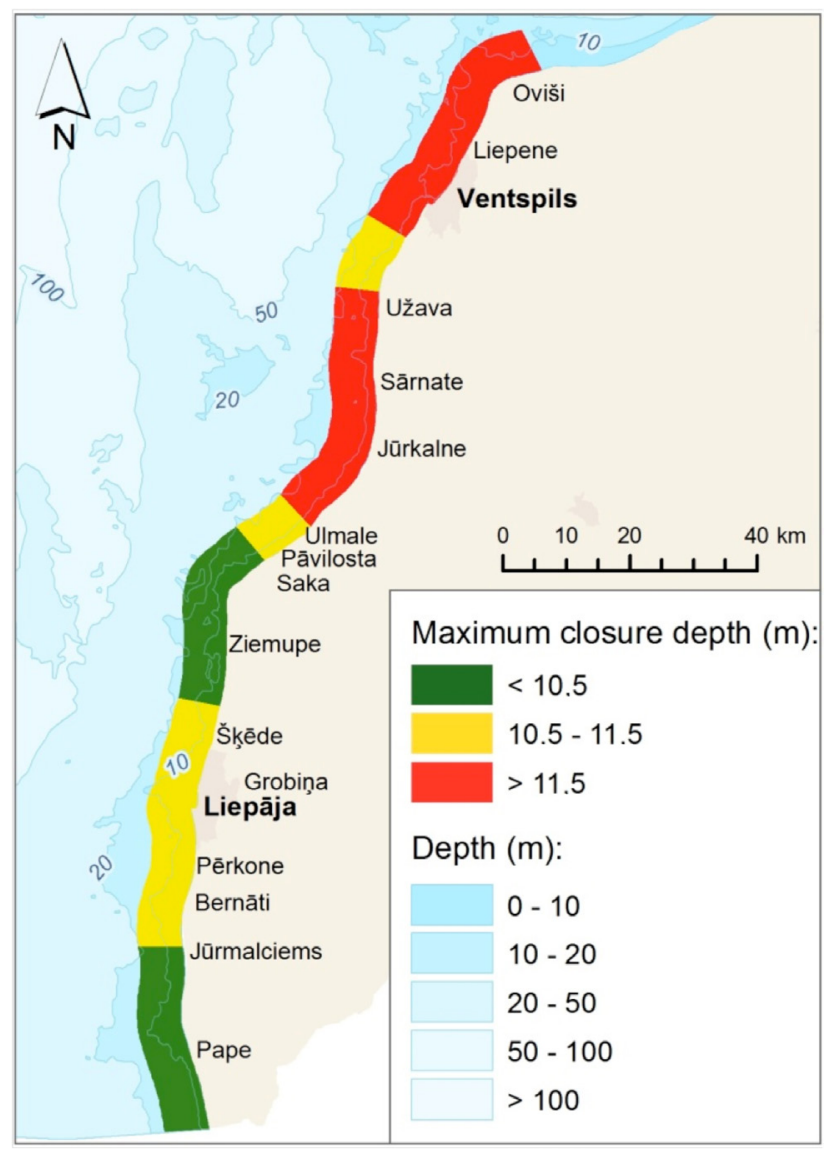

Fig. 5. Gradual division of the maximum closure depth in the study area. The designated division of the parameter is not based on an actual scale and has only informative meaning. 
sediment transport intensity along the coastal zone of the study site was rather intermittent (Fig. 6). The net amount of transported sedimentary material can vary between 1 and 2.6 million $\mathrm{m}^{3}$ annually. A smaller amount of sedimentary material was transported in the coastal areas between the Latvian-Lithuanian border and Liepāja, between Šksēde and Ziemupe villages and in the area around Miķeltornis. The largest estimated transport of sedimentary material was common for the coastal zone between Saka and Jürkalne villages and between Sārnate and Oviši villages, where it can exceed 2 million $\mathrm{m}^{3}$ annually. For the remaining areas, the calculated amount of transported sedimentary material varied between 1.5 and 2 million $\mathrm{m}^{3}$ annually.

Soomere and Viška (2013) pointed out that using the CERC approach in areas with rocky seabed can lead to an overestimation of the sediment transport. Although the seabed composition of the study area was highly mosaic, for more localized areas with predominantly rocky seabed sediment transport could be lower than estimated. For areas with a sedimentary seabed, the CERC approach gives adequate estimates of sediment transport (Soomere, Viška 2013). Nevertheless, in context of physical impact on biodiversity, these results should be interpreted carefully, because high sediment transport intensity can also indicate

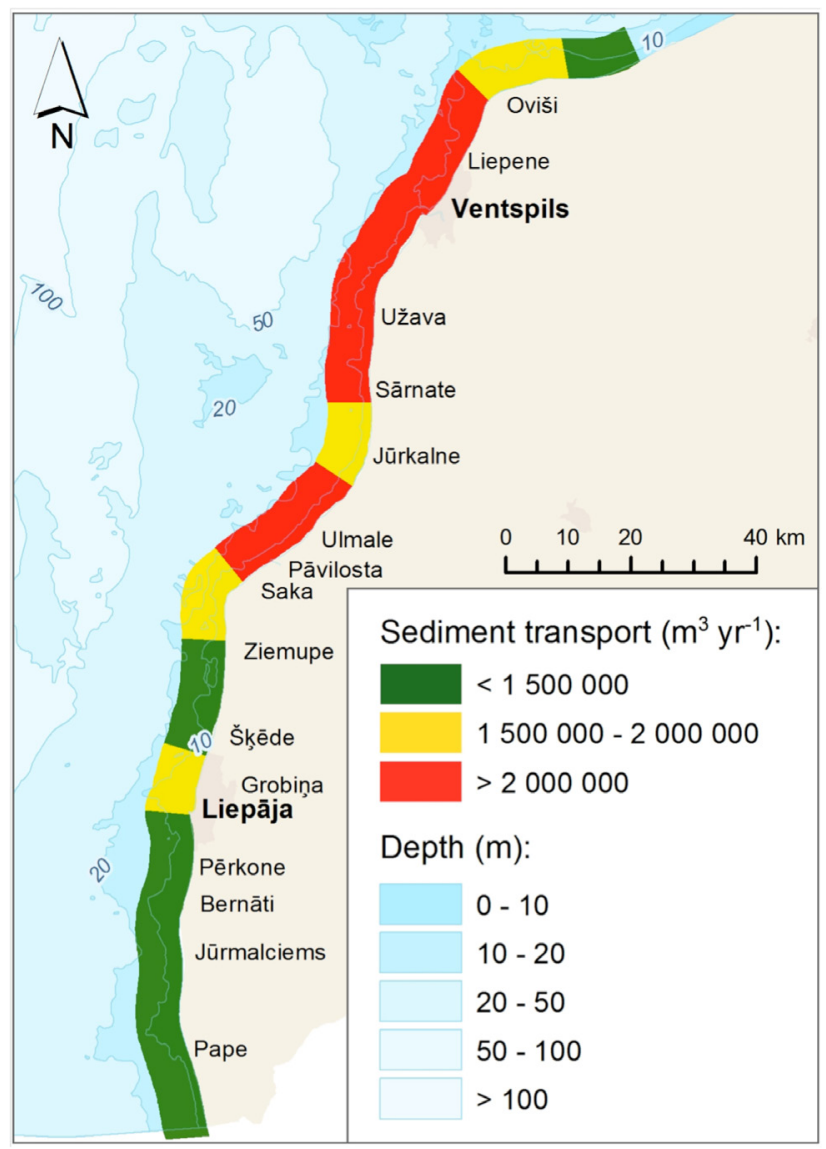

Fig. 6. Gradual division of the sediment transport rate in the study area. The designated division of the parameter is not based on an actual scale and has only informative meaning. areas with completely sandy seabed with no coastal habitats to affect.

\section{Physical impact index}

The obtained data on wave properties and sediment transport intensity allow to estimate the physical impact index, determined as a cumulative effect of 12-h average and maximum wave heights, closure depth and sediment transport intensity. As the values of these parameters cannot be directly compared because they are expressed in different units and characterize different processes, they were expressed as percentage deviation from the average value, resulting in maximum and minimum physical impact index determined as upper and lower $30^{\text {th }}$ percentile respectively.

In accordance to wave activity, the physical impact index increased from south to north (Fig. 7). The lowest physical index occurred in the coastal zone between the Latvian-Lithuanian border and Bernāti village, and in the zone around Šksēde village. This section of the coastal zone is located in the the marine protected area "Nida Pērkone", where $80 \%$ of the area is covered by stony reefs that provide habitat for macrophytes, mussel and barnacle species (Baltic Environmental Forum Latvia 2009). This

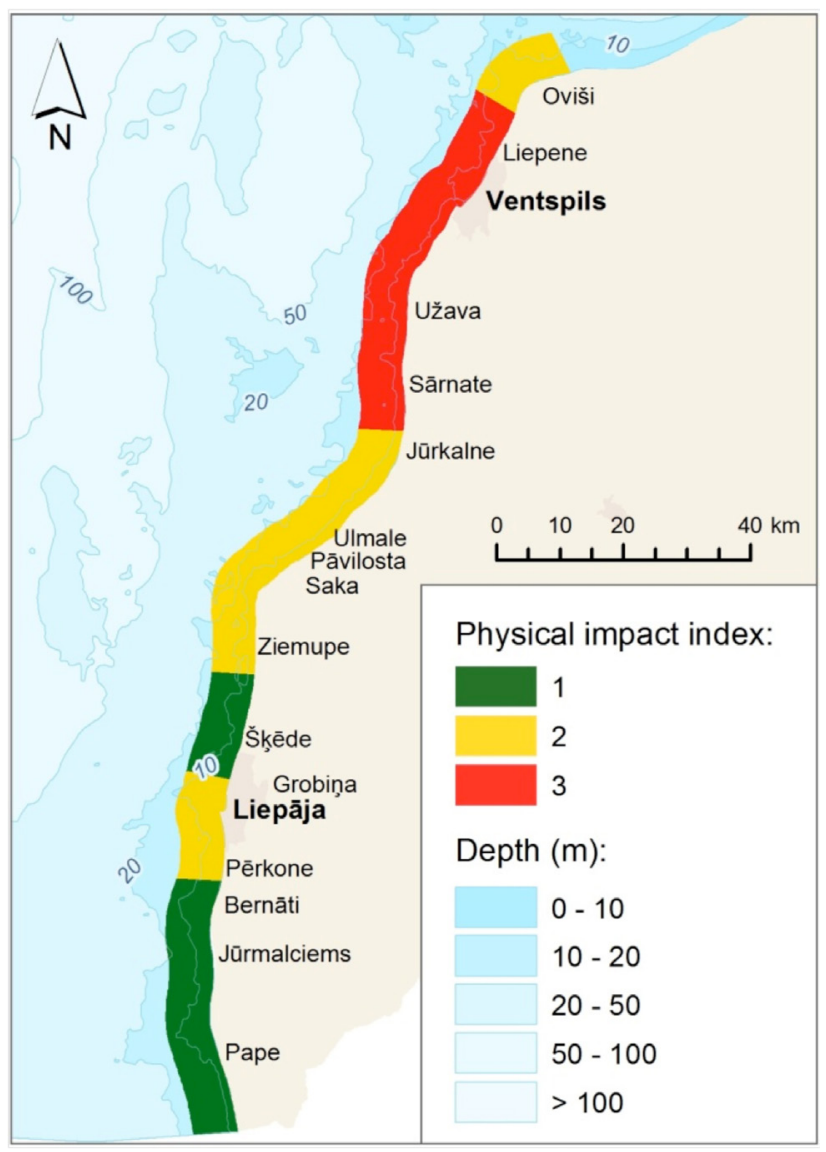

Fig. 7. Gradual division of the physical impact index in the study area. The designated division of the parameter is not based on an actual scale and has only informative meaning. 
area is also included in the Red List of Marine and Coastal Biotopes and Biotope Complexes of the Baltic Sea, Belt Sea and Kattegat (HELCOM 1998). The highest estimated physical impact on coastal habitats occurred in the section from Jürkalne to north of Liepene village, where the effect of wave influence and sediment transport intensity was above the average value of the whole study site. The coastal zone with high physical impact index includes a small part of the marine protected area in the Irbe strait, while medium physical impact index was estimated to occur in marine protected area in Akmensrags. However, field data to assess the potential value of the coastal reef habitats in these areas were not available.

Parameters causing physical impact were estimated for about 5.5 to $7 \mathrm{~km}$ wide zone along the coast. Within that zone the depth exceeded $10 \mathrm{~m}$ (Fig. 7). However, the depth dimension of the physical impact index is defined by the estimated average and maximum closure depth, which were 6.8 and $11.5 \mathrm{~m}$ for everyday wave conditions and storm events, respectively. This indicates that the estimated physical impact is suitable for coastal territories with up to $6.8 \mathrm{~m}$ of depth, but it becomes overestimated with increasing distance from the coastline, where the depth can exceed the average and maximum potential closure depth. In addition, due to the highly fragmented underwater landscape in the study area, completely sandy zones can interchange with predominantly rocky seabed within the area of a single wave model cell. Furthermore, it is highly possible that due to severe storms some sandy areas can be reallocated to another place, e.g., if sand is deposited on top of rocky bottom the area becomes sandy, and vice versa. Strong storms create sufficient wave energy and depth penetration to transport sand patches. Therefore, the estimated impact index should not be applied for smaller areas than in the wave model cell. Furthermore, the estimation of impact on biodiversity should be based on a finer observation grid of biodiversity parameters, rather than on the wave model cell grid, in order to provide sufficient number of replicates to correctly estimate status of biological community in relation to physical impact.

\section{Acknowledgements}

The study "Climate change impact on biodiversity of Baltic Sea coastal reefs" was financed by the EEA grant. Project No. 2/ EEZLV02/14/GS/022.

\section{References}

Andrulewicz E., Kruk-Dowgiallo L., Osowiecki A. 2004. Phytobenthos and macrozoobenthos of the Slupsk Bank stony reefs, Baltic Sea. Hydrobiologia 514: 163-170.

Baltic Environmental Forum Latvia. 2009. Nature conservation plan for the marine protected area "Nida-Pērkone". The Nature Conservation Agency. 95 p. /in Latvian/

Baltic Environmental Forum Latvia. 2015. Maritime spatial plan for Territorial sea and exclusive economic zone of the Republic of Latvia. Ministry of Environmental Protection and Regional Development, Republic of Latvia. 173 p. /in Latvian/ Birkemeier W.A. 1985. Field data on seaward limit of profile change. J. Waterw. Port. Coast. Div. 111: 598-602.

Brohan P., Kennedy J.J., Harris I., Tett S.F.B., Jones P.D. 2006. Uncertainty estimates in regional and global observed temperature changes: a new dataset from 1850. J. Geophys. Res. 111: D12106.

Eberhards G., Lapinskis J. 2008. Processes on the Latvian Coast of the Baltic Sea. Atlas. University of Latvia, Riga.

Eriksson C., Omsted A., Overland J.E., Percival D.B., Mofjeld H.O. 2007. Characterizing of European sub-Arctic winter climate since 1500 using ice, temperature, and atmospheric circulation time series. J. Climate 20: 5316-5334.

HELCOM. 1998. Red List of Marine and Coastal Biotopes and Biotope Complexes of the Baltic Sea, Belt Sea and Kattegat. Baltic Sea Environment Proceedings No. 75.

HELCOM. 2013. Climate change in the Baltic Sea Area: HELCOM thematic assessment in 2013. Balt. Sea Environ. Proc. No. 137

Houston J.R. 1996. Simplified Dean's method for beach-fill design. J. Waterw. Port. Coast. Div. 122: 143-146.

Komen G.J., Cavaleri L., Donelan M., Hasselmann K., Hasselmann S., Janssen P.A.E.M. 1994. Dynamics and Modeling of Ocean Waves. Cambridge University Press, Cambridge.

Kudryavtseva N.A., Soomere T. 2016. Validation of the multimission altimeter data for the Baltic Sea region. Proc. Estonian Acad. Sci. arXiv:1603.08698v1 /submitted/

Lapinskis J. 2010. Dynamics of the Kurzeme coast of the Baltic Proper. PhD thesis. University of Latvia, Riga, 112 pp. /in Latvian/

Nature Conservation Agency. 2010. The list of Natura 2000 territories in Latvia. The Nature Conservation Agency of Latvia. http://www.daba.gov.lv/upload/File/DOC/IADT_ N2000_list.pdf

Pranzini E., Williams A. 2013. Coastal Erosion and Protection in Europe. Routledge, Taylor and Francis, Abingdon-New York.

Räämet A., Soomere T. 2010. The wave climate and its seasonal variability in the northeastern Baltic Sea. Estonian J. Earth Sci. 59: 100-113.

Soomere T., Keevallik S. 2001. Anisotropy of moderate and strong winds in the Baltic Proper. Proc. Estonian Acad. Sci. Eng. 7: $35-49$.

Soomere T., Viška M., Lapinskis J., Räämet A. 2011. Linking wave loads with the intensity of erosion along the coasts of Latvia. Estonian J. Eng. 17: 359-374.

Soomere T., Viska M. 2013. Simulated wave-driven sediment transport along the eastern coast of the Baltic Sea. J. Marine Syst. 129: 96-105.

Soomere T., Viska M., Eelsalu M. 2013. Spatial variations of wave loads and closure depths along the coast of the eastern Baltic Sea. Estonian J. Eng. 19: 93-109.

Ulsts V. 1998. Latvian Coastal Zone of the Baltic Sea. Riga. /in Latvian/

USACE. 2002. Coastal Engineering Manual. Department of the Army. U.S. Army Corps of Engineers. Manual No. 1110-21100.

Viška M., Soomere T. 2013. Simulated and observed reversals of wave-driven alongshore sediment transport at the eastern Baltic Sea coast. Baltica 26: 145-156. 